\title{
Silicon does not alleviate the adverse effects of drought stress in soybean plants
}

\section{O silício não alivia os efeitos adversos do estresse hídrico em plantas de soja}

\author{
Viviane Ruppenthal ${ }^{1}$; Tiago Zoz ${ }^{2}$; Fábio Steiner ${ }^{*}$; \\ Maria do Carmo Lana ${ }^{3}$; Deise Dalazen Castagnara ${ }^{4}$
}

\begin{abstract}
Beneficial effects of silicon $(\mathrm{Si})$ in the plants growth under conditions of drought stress have been associated with to uptake and accumulation ability of element by different species. However, the effects of $\mathrm{Si}$ on soybean under water stress are still incipient and inconclusive. This study investigated the effect of Si application as a way to confer greater soybean tolerance to drought stress. The experiment was carried out in $20-\mathrm{L}$ pots under greenhouse conditions. Treatments were arranged in a randomized block design in a $2 \times 4$ factorial: two water regimes (no stress or water stress) and four Si rates $(0,50$, 100 and $200 \mathrm{mg} \mathrm{kg}^{-1}$ ). Soybean plants were grown until beginning flowering (R1) growth stage with soil moisture content near at the field capacity, and then it started the differentiation of treatments under drought by the suspension of water supply. Changes in relative water content (RWC) in leaf, electrolyte leakage from cells, peroxidase activity, plant nutrition and growth were measured after 7 days of drought stress and 3 days recovery. The RWC in soybean leaves decreased with Si rates in the soil. Silicon supply in soil with average content of this element, reduced dry matter production of soybean under well-irrigated conditions and caused no effect on dry matter under drought stress. The nitrogen uptake by soybean plants is reduced with the Si application under drought stress. The results indicated that the Si application stimulated the defense mechanisms of soybean plants, but was not sufficient to mitigate the negative effects of drought stress on the RWC and dry matter production.
\end{abstract}

Key words: Glycine max. Water deficit. Electrolyte leakage from cells. Peroxidase activity.

\section{Resumo}

Os efeitos benéficos do silício ( $\mathrm{Si}$ ) no crescimento das plantas sob condições de déficit hídrico têm sido associados com a capacidade de absorção e acumulação deste elemento pelas diferentes espécies de plantas. No entanto, os efeitos de Si na cultura da soja em condições de déficit hídrico ainda são incipientes e inconclusivos. Este estudo investigou o efeito da aplicação de $\mathrm{Si}$, como forma de conferir maior tolerância da soja ao estresse hídrico. O experimento foi conduzido em vasos de $20 \mathrm{~L} \mathrm{em} \mathrm{condições}$ de casa de vegetação. Os tratamentos foram dispostos em um delineamento em blocos casualizados, em esquema fatorial $2 \times 4$ : dois regimes hídricos (sem ou com estresse hídrico) e quatro doses de $\mathrm{Si}(0,50$, 100 e $200 \mathrm{mg} \mathrm{kg}^{-1}$ ). As plantas de soja foram cultivadas até o início do florescimento (R1) com a teor

${ }^{1} \mathrm{Dr}^{\mathrm{a}}$ em Agronomia, Departamento de Fitotecnia, Universidade Federal do Ceará, UFC, Fortaleza, CE, Brasil. E-mail: viviruppenthal@hotmail.com

2 Prof. Adjunto, Departamento de Agronomia, Universidade Estadual de Mato Grosso do Sul, UEMS, Cassilândia, MS, Brasil. E-mail: zoz@uems.br; steiner@uems.br

${ }^{3}$ Prof $^{a}$ Adjunto, Departamento de Agronomia, Universidade Estadual do Oeste do Paraná, UNIOESTE, Marechal Cândido Rondon, PR, Brasil. E-mail: maria.lana@unioeste.br

${ }^{4}$ Prof ${ }^{a}$ Adjunto, Universidade Federal do Pampa, UNIPAMPA, Uruguaiana, RS, Brasil. E-mail: deisecastagnara@yahoo.com.br

* Author for correspondence 
de umidade do solo próximo à capacidade de campo, e então começou a diferenciação dos tratamentos sob déficit hídrico mediante a suspensão do fornecimento de água. Alterações no conteúdo relativo de água (CRA), extravasamento de eletrólitos das células, atividade de peroxidase, nutrição e crescimento das plantas foram mensurados após 7 dias de expossição do déficit hídrico e após 3 dias de recuperação. O CRA das folhas de soja diminuiu com a aplicação das doses de Si no solo. A aplicação de Si em solo com teor médio desse elemento resultou na redução da produção de matéria seca da soja no tratamento sem déficit hídrico e não causou efeito na produção de matéria seca em condições de déficit hídrico. A absorção de nitrogênio pelas plantas de soja foi reduzida com a aplicação de Si em condições de déficit hídrico. Os resultados deste estudo indicaram que a aplicação de Si estimulou os mecanismos de defesa das plantas de soja, mas não foi suficiente para minimizar os efeitos negativos do estresse hídrico no CRA e na produção de matéria seca das plantas.

Palavras-chave: Glycine max. Déficit hídrico. Extravasamento de eletrólitos das células. Atividade de peroxidase.

\section{Introduction}

Drought stress is environmental condition that constrains plants to express their ecophysiological potential, causing short and long term effects in different hierarchical levels, from biochemical to morphological ones, and affecting crop yield (SOUZA; CARDOSO, 2003). Water deficit leads invariably to a decrease in photosynthetic rate, leaf area, transpiration and growth rate (GAO et al., 2006; KRON et al., 2008), as well as modification of activity of enzymes of carbon and nitrogen metabolism and changes in the antioxidants levels (GONG et al., 2005; FLEXAS et al., 2006; GUNES et al., 2008). Some of these responses are part of strategies that aimed to reduce the deleterious effects of low water availability of soil, constituting, so, mechanisms of drought tolerance.

The calcium and magnesium silicate can be used as corrective of soil acidity and silicon ( $\mathrm{Si}$ ) source (PULZ et al., 2008; CRUSCIOL et al., 2009; SARTO et al., 2015). Silicon is not considered an essential element for plant growth. Its beneficial effects are normally observed under stressing conditions to plants (MA; YAMAJI, 2006), and several studies have demonstrated that Si plays an important role in plant tolerance to environmental stresses (GONG et al., 2005; CRUSCIOL et al., 2009; MAUAD et al., 2011). These beneficial effects are attributed to $\mathrm{Si}$ deposited in the cell wall of various plant organs (MA, 2004; MA; YAMAJI, 2006) and other mechanisms. High deposition of $\mathrm{Si}$ in tissues forms a physical barrier that enhances the strength and rigidity of the tissues. However, there is evidence that the beneficial effects of Si to plants are related to ability of species to accumulate this element. The difference in Si accumulation of different plant species has been ascribed to the ability of the roots to take up Si (MITANI; MA, 2005). In general, only a few crop species of Gramineae and Cyperacea show high $\mathrm{Si}$ accumulation (HATTORI et al., 2005). Soybean containing between 5.0-10.0 $\mathrm{g} \mathrm{kg}^{-1}$ of $\mathrm{Si}$ in the shoot, and has been classified as a specie intermediate $\mathrm{Si}$ accumulation (DESHMUKH et al., 2013).

In conditions of drought stress, beneficial effect of Si has been attributed to increase in the capacity of antioxidant defenses (GONG et al., 2005; GUNES et al., 2008) and maintenance of the photosynthetic rate, relative water content in leaves, stomatal conductance of the plant, even in dry soil (HATTORI et al., 2005; FERRAZ et al., 2014) due to reduced transpiration rate (MA; YAMAJI, 2006) and electrolyte leakage from cells (AGARIE et al., 1998). Miao et al. (2010) showed that the Si increases tolerance of soybean plants to nutrient toxicity, as well as ameliorates symptoms associated with deficiency in essential nutrients in plants. However, there is no information in the literature that indicates whether the Si applications has beneficial effects on soybean under drought stress. Soybean is an intermediate plant in the $\mathrm{Si}$ accumulation, thus it was expected that the 
application of Si alleviates the deleterious effects of drought stress. This research was carried out to investigate the effects of Si fertilization on nutrition and growth of soybean under drought stress.

\section{Material and Methods}

Pot experiment was carried out in a greenhouse in Marechal Cândido Rondon, Paraná, Brazil ( $24^{\circ} 31^{\prime} \mathrm{S}, 54^{\circ} 01^{\prime} \mathrm{W}$, and $420 \mathrm{~m}$ ), where the environmental conditions were: mean temperature of $26^{\circ} \mathrm{C}\left( \pm 2{ }^{\circ} \mathrm{C}\right)$, air relative humidity of $66 \%( \pm$ $4 \%$ ) and light fluence of $680 \pm 220 \mu \mathrm{mol} \mathrm{m} \mathrm{m}^{-2} \mathrm{~s}^{-1}$ photosynthetic photon flux density (PPFD). The soil used in the experiment was collected from the layer of a clayey Rhodic Hapludox (Red Latosol in the Brazilian classification) with $620 \mathrm{~g} \mathrm{~kg}^{-1}$ of clay, $110 \mathrm{~g} \mathrm{~kg}^{-1}$ of silt, and $270 \mathrm{~g} \mathrm{~kg}^{-1}$ of sand. The soil had the following properties: $\mathrm{pH}\left(1: 2.5\right.$ soil $/ \mathrm{CaCl}_{2}$ suspension $0.01 \mathrm{M}) 5.5,21 \mathrm{~g} \mathrm{dm}^{-3}$ organic matter, $41 \mathrm{mg} \mathrm{dm}^{-3} \mathrm{P}_{\text {Mehlich-1 }}, 51 \mathrm{mmol}_{\mathrm{c}} \mathrm{dm}^{-3}$ of Ca, $17 \mathrm{mmol}_{\mathrm{c}}$ $\mathrm{dm}^{-3}$ of $\mathrm{Mg}, 10 \mathrm{mmol}_{\mathrm{c}} \mathrm{dm}^{-3}$ of K, $52 \mathrm{mmol}_{\mathrm{c}} \mathrm{dm}^{-3}$ of $\mathrm{H}+\mathrm{Al}, 130 \mathrm{mmol}_{\mathrm{c}} \mathrm{dm}^{-3}$ of CEC, $60 \%$ of base saturation, $15 \mathrm{mg} \mathrm{dm}^{-3}$ of $\mathrm{Cu}_{\text {Mehlich-1 }}, 6.7 \mathrm{mg} \mathrm{dm}^{-3}$ of $\mathrm{Zn}_{\text {Mehlich-1 }}$, and $22 \mathrm{mg} \mathrm{dm}^{-3}$ of Si (Acetic acid). All the soil chemical properties were analyzed according to Embrapa (2009). The field capacity of the soil sample under free draining was measured at -0.03 MPa using the Richards extractor (EMBRAPA, 1997) and the value obtained was $280 \mathrm{~g} \mathrm{~kg}^{-1}$.

The experimental was arranged in a randomized block design, using four levels for the Si rate factor $\left(0,50,100\right.$ and $200 \mathrm{mg} \mathrm{kg}^{-1}$ of Si) and two levels for the drought stress factor (no water stress and water stress), considering a factorial arrangement $(4 \times 2)$. A total of 64 pots were used -8 pots per treatment. Four replicates were used as destructive samples, including leaf area (LA), shoot and root dry matter of soybean after 7 days of drought stress. The other four pots were used for the measurement of leaf relative water content, electrolyte leakage from cells, peroxidase activity and foliar diagnosis after 7 days of drought stress and after 3 days' recovery of soybean plants. The Si source was applied at 14 days before soybean sowing using calcium and magnesium silicate $(10 \% \mathrm{Si} ; 25 \% \mathrm{Ca}$ and $6 \% \mathrm{Mg})$, and. The basic fertilization was carried out with applying $40 \mathrm{mg} \mathrm{kg}^{-1}$ of $\mathrm{N}$ (ammonium nitrate), 150 $\mathrm{mg} \mathrm{kg}^{-1}$ of $\mathrm{P}$ (simple superphosphate), $100 \mathrm{mg} \mathrm{kg}^{-1}$ of $\mathrm{K}$ (potassium chloride), $5 \mathrm{mg} \mathrm{kg}^{-1}$ of $\mathrm{Cu}$ (copper sulfate), $5 \mathrm{mg} \mathrm{kg}^{-1}$ of $\mathrm{Zn}$ (zinc sulfate), $1 \mathrm{mg} \mathrm{kg}^{-1}$ of Mo (ammonium molybdate) and $2 \mathrm{mg} \mathrm{kg}^{-1}$ of B (boric acid).

Five seeds of soybean [Glycine max L. (Merrill), cv. V-Max] were sown in plastic pots containing 20-L of soil, and nine days after seedling emergence, they were thinned to two plants per pot. The pots had the soil surface covered with a layer about $20 \mathrm{~mm}$ of straw, with the goal of reducing water loss through evaporation. Until beginning flowering (R1) growth stage, the soil water content was maintained near at the field capacity with daily irrigation (from 230 to $260 \mathrm{~g} \mathrm{~kg}^{-1}$ of water). Posteriorly, it started the differentiation of treatments under water stress by the suspension of water supply in 32 pots. The treatments of water stress remained without water replacement until the relative water content in leaves reached nearly $50 \%$, that due the environmental conditions, occurred seven days after imposition of water deficit. Then, was carried the rehydration of treatments in water deficit, being then, the whole experiment conducted without water deficiency for three days. In a previous experiment, a threeday period was sufficient for the full recovery of soybean plants subjected to drought stress.

Relative water content (RWC) and electrolyte leakage (EL)

During the period of exposure to water deficit and recovery of the plants was determined the relative water content (RWC) in leaf tissues and soil moisture content (SMC). The RWC indicates the water content of a given amount of leaf relative to its fully hydrated or fully turgid state and was determined using the following equation proposed 
by Barrs (1968): RWC $=[(\mathrm{FM}-\mathrm{DM}) /(\mathrm{TM}-\mathrm{DM})]$, where FM, DM and TM are fresh mass, dry mass and turgid mass, respectively. Soil moisture content (SMC, $\mathrm{g} \mathrm{kg}^{-1}$ ) was determined by gravimetric method as described by Embrapa (1997).

Electrolyte leakage was assessed after 7 days of drought stress and 3 days' recovery as described by Lutts et al. (1996). Leaf discs were placed in closed tubes containing $30 \mathrm{~mL}$ of deionized water and incubated at $25{ }^{\circ} \mathrm{C}$ in a water bath for $6 \mathrm{~h}$; subsequently, the electrical conductivity of the solution (L1) was determined. Samples were then boiled at $100{ }^{\circ} \mathrm{C}$ for $1 \mathrm{~h}$, and the last electrical conductivity (L2) was obtained after equilibration at $25{ }^{\circ} \mathrm{C}$. The electrolyte leakage (EL) was defined as follows: $\operatorname{EL}(\%)=(\mathrm{L} 1 / \mathrm{L} 2) \times 100$.

Peroxidase activity was also determined after 7 days of drought stress and 3-d recovery. The central leaves of the trifoliate from the middle third of plants were collected. The collected material (about $2.0 \mathrm{~g}$ ) was weighed and macerated in $4 \mathrm{~mL}$ of phosphate buffer $0.01 \mathrm{~mol} \mathrm{~L}^{-1}(\mathrm{pH} 6.0)$ at $4{ }^{\circ} \mathrm{C}$. The homogenate was centrifuged at $14,000 \mathrm{rpm}$ for $20 \mathrm{~min}$ and the supernatant collected. In glass bucket with capacity of $3.0 \mathrm{~mL}$, were added $2.8 \mathrm{~mL}$ of reaction buffer (306 $\mu \mathrm{L}$ of $\mathrm{H}_{2} \mathrm{O}_{2}+12.5 \mathrm{~mL}$ of guaiacol $2 \%$ in 87.5 $\mathrm{mL}$ of extraction buffer) and $0.2 \mathrm{~mL}$ of supernatant. The reaction was followed by spectrophotometer at $470 \mathrm{~nm}$ for 2 minutes (HAMMERSCHMIDT et al., 1982). The unit of peroxidase activity was defined with the increase of one unit of absorbance per min $^{-}$ ${ }^{1} \mathrm{mg}^{-1}$ of fresh matter.

After 7 days of exposure to water deficit the dry matter production of shoots (SDM, g/plant) and roots (RDM, g/plant) was evaluated. Plants of all treatments were harvested separately, dried for four days at $60{ }^{\circ} \mathrm{C}$, and then weighed. The leaf area (LA, $\mathrm{cm}^{2} /$ plant) was determined using the following equation proposed by Benincasa (2003): $\mathrm{LA}=[(\mathrm{LAs} \times \mathrm{TDML}) / \mathrm{DMs}]$, where LAs is the leaf area of the sample collected, TDML is the total dry matter of leaf and DMs is the dry matter of the sample collected.

Soybean leaves of the trifoliate from the middle third of plants were also collected for foliar diagnosis. The samples were dried in a forced-air oven for $72 \mathrm{~h}$ at $65{ }^{\circ} \mathrm{C}$, ground, digested in nitricperchloric acid and $\mathrm{P}$ was determined by colorimetry, $\mathrm{K}$ content were determined by flame photometry, $\mathrm{N}$ by sulfuric acid digestion and vapor distillation (EMBRAPA, 2009), and Si by hydrogen peroxide and sodium hydroxide digestion and determined by colorimetry (KORNDÖRFER et al., 2004).

\section{Statistical analyses}

Data were subjected to analysis of variance and the means of water regimes were compared by F-test at the 0.05 level of confidence. For the Si rates were used regression analysis and significant equations with the greatest determination coefficients were adjusted ( $\mathrm{p} \leq 0.05)$. All analyses were performed using Sigma Plot 11.0 software for Windows (Systat Software, Inc., San Jose, CA, USA).

\section{Results and Discussion}

A summary of the analysis of variance for the measurements of electrolyte leakage, peroxidase activity, nutrition and growth of soybean plants is shown in Table 1. Analysis of variance showed that there were significant differences $(\mathrm{P}<0.05)$ between water regimes for all traits except root dry matter, $\mathrm{N}$ and $\mathrm{P}$ concentration in soybean leaves. The results revealed that different rates of $\mathrm{Si}$ had a significant $(\mathrm{P}<0.05)$ effect on most of the traits measured, except membrane damage at $3^{\text {nd }}$ day recovery, $\mathrm{P}$ and $\mathrm{K}$ concentration in soybean leaves. Analysis of variance also showed that interaction effects were significant $(\mathrm{P}<0.05)$ for most of the investigated traits except membrane damage at $3^{\text {nd }}$ day recovery, leaf area and $\mathrm{P}$ and $\mathrm{K}$ concentration in soybean leaves (Table 1). 
Table 1. Summary of the analysis of variance for the measurements of electrolyte leakage, peroxidase activity, nutrition and growth of soybean plants as affected by Si fertilization and drought stress.

\begin{tabular}{lccccccccccccc}
\hline Causes of & \multicolumn{10}{c}{ Probability $>\mathrm{F}$} \\
\cline { 2 - 16 } variation & $\mathrm{MD}_{7}$ & $\mathrm{MD}_{3}$ & $\mathrm{PA}_{7}$ & $\mathrm{PA}_{3}$ & $\mathrm{LA}$ & $\mathrm{SDM}$ & $\mathrm{RDM}$ & $\mathrm{TDM}$ & $\mathrm{N}$ & $\mathrm{P}$ & $\mathrm{K}$ & $\mathrm{Si}$ \\
\hline Drought (D) & 0.041 & 0.030 & 0.012 & $<0.000$ & $<0.000$ & 0.018 & 0.142 & 0.041 & 0.105 & $<0.000$ & 0.216 & $<0.000$ \\
Silicon (Si) & $<0.000$ & 0.098 & 0.004 & $<0.000$ & 0.036 & 0.048 & 0.040 & 0.008 & 0.045 & 0.187 & 0.128 & $<0.000$ \\
$\mathrm{D} \times \mathrm{Si}$ & $<0.000$ & 0.124 & 0.002 & $<0.000$ & 0.197 & 0.033 & 0.003 & $<0.000$ & $<0.000$ & 0.473 & 0.313 & $<0.000$ \\
$\mathrm{CV}(\%)$ & 8.6 & 9.7 & 10.8 & 14.2 & 12.3 & 7.8 & 15.1 & 9.6 & 10.7 & 8.4 & 12.1 & 13.7 \\
\hline
\end{tabular}

$\mathrm{MD}_{7}$ : membrane damage after $7^{\text {th }}$ day of exposure to drought. $\mathrm{MD}_{3}$ : membrane damage after $3^{\text {nd }}$ day recovery under well-irrigated conditions. $\mathrm{PA}_{7}$ : Peroxidase activity after $7^{\text {th }}$ day of exposure to drought. PA 3 : Peroxidase activity after $3^{\text {nd }}$ day recovery under wellirrigated conditions. LA: leaf area. SDM: shoot dry matter. RDM: Root dry matter. N: Nitrogen. P: Phosphorus. K: Potassium. Si: Silicon.

Soil moisture content and relative water content $(R W C)$ in leaf tissues

The soil moisture content (SMC) remained constant in the treatments under normal irrigation supply (well-irrigated conditions), varying from 230 to $260 \mathrm{~g} \mathrm{~kg}^{-1}$ (Figure 1). In treatments with water deficit, the desiccation of the soil occurred rapidly, being that the SMC passed from 230 $\mathrm{g} \mathrm{kg}^{-1}$ on the first day to $175 \mathrm{~g} \mathrm{~kg}^{-1}$ on the third day, due to conditions of high temperature and low relative humidity of the air increasing the soil water withdrawal by plant. After the third day of exposure to drought stress, the SMC changed little until the seventh day when the rehydration occurred. As the soil dries, it becomes more difficult for plants to absorb water, because retention force increases and the soil water availability to plants decreases (SANTOS; CARLESSO, 1998). Water supply (rehydration) in the seventh day of exposure to drought stress increased of SMC to values similar to the treatment under well-irrigated conditions (Figure 1).

Figure 1. Soil moisture content (SMC) at pre-dawn during the 7 days of exposure to drought stress and 3 days recovery of the soybeans plants under well-irrigated conditions.

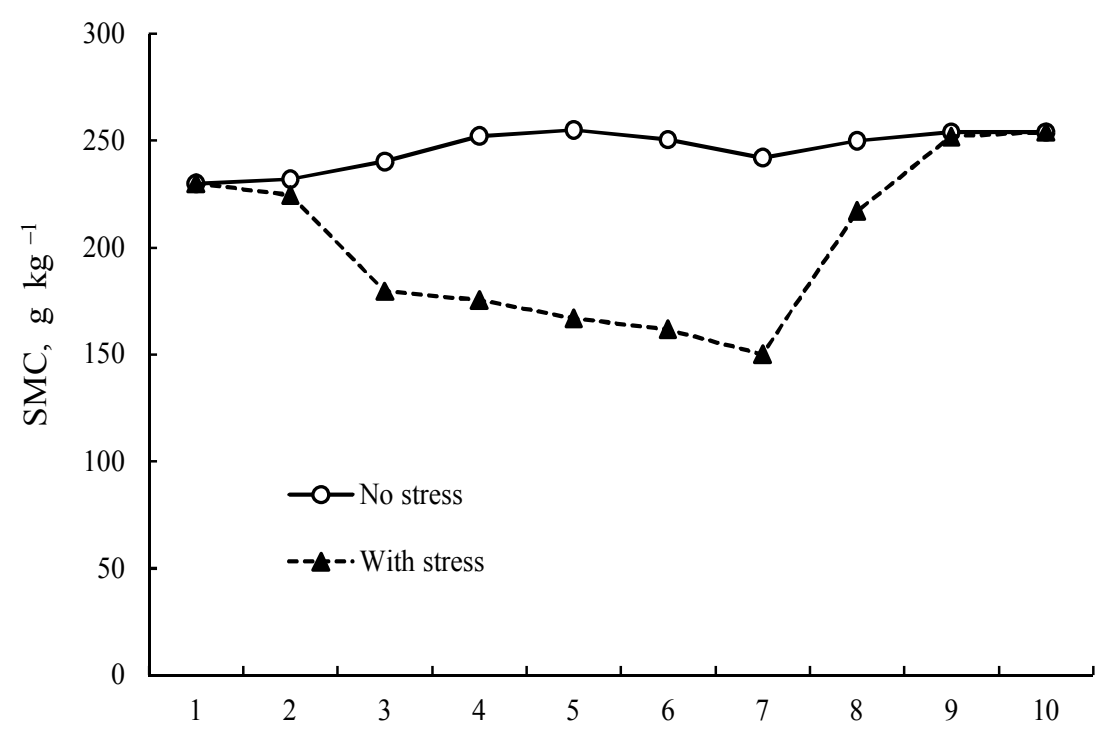

Day after the beginning of drought stress 
The relative water content (RWC) in soybean leaves remained constant (90 to $95 \%$ ) in the treatments under normal water supply (Figure 2). In treatments with water deficit, the RWC in soybean leaves decreased with the days of exposure to drought stress, reaching the lowest value in the seventh day (Figure 2). The reduction of RWC from the second day of exposure to drought stress was due to the decrease of soil water availability (Figure 1). On the second day after rehydration, the RWC of treatments with stress was similar to values observed under well-irrigated conditions. The maintenance of cells turgor in water stress conditions enables a rapid recovery of the plant in the case of rehydration and can give continuity to the processes affected in a short period (CHAVES et al., 2002).

Figure 2. Relative water content in the leaves (RWC) at pre-dawn during the 7 days of exposure to drought stress and 3 days recovery of the soybean plants under well-irrigated conditions as affected by application of silicon (Si). Vertical bars represent standard deviation of the mean $(n=4)$.

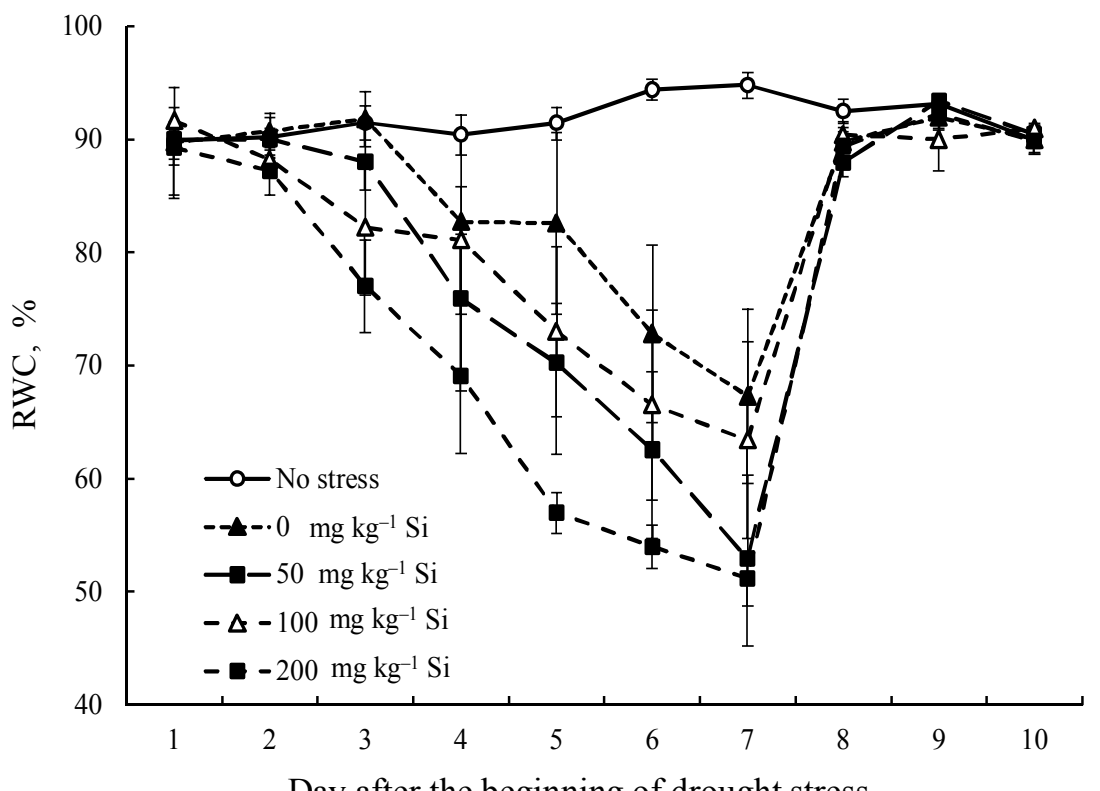

Silicon supply negatively affected the RWC in soybean leaves from the third day of exposure to drought stress (Figure 2). The RWC decreased progressively with increasing $\mathrm{Si}$ rates in the soil, reporting the highest sensitivity of soybean plants to the reduced of soil water availability. Gao et al. (2006) reported that the addition of Si increased water use efficiency by reducing leaf transpiration and the water flow rate in the xylem vessel in maize. Silicon could facilitate water uptake and transport in forage sorghum under drought conditions (HATTORI et al., 2005). These beneficial effects are attributed to Si deposited in the cell wall of various plant organs (MA, 2004; MA; YAMAJI, 2006) and other mechanisms. However, this beneficial effect on soybean plants under conditions of drought stress - a species with intermediate ability to accumulate $\mathrm{Si}$ is not true as verified in this study. The uptake and radial distribution of Si through the soybean roots to the xylem vessels are more restricted to high Si concentrations, which may indicate an effective exclusion mechanism (MARSCHNER, 1995). It is emphasized, however, that even with this increased susceptibility to water stress, after rehydration recovery of water status of soybean plants was rapid and similar for all Si rates. 
Electrolyte leakage from cells and peroxidase activity

The electrolyte leakage from cells of soybean leaves under well-irrigated conditions were not affected by Si rates in both evaluations (Figure 3a and $3 \mathrm{~b}$ ). In general, the higher electrolyte leakage from cells of soybean leaves was observed under drought conditions. The electrolyte leakage occurs under conditions of drought stress due to the increased amount of reactive oxygen species (ROS), free radicals and enzymes "lysis" (FOYER et al., 1994), resulting in breakage and increased membrane damage. Increased of electrolyte leakage a result of increased membrane permeability under drought stress were also reported in other plant species, such as rice (AGARIE et al., 1998) and wheat (BELTRANO; RONCO, 2008).

Figure 3. Effects of silicon ( $\mathrm{Si}$ ) application rates on the membrane damage (MD, in $\mathrm{A}-\mathrm{B})$ and peroxidase activity (PA, in $\mathrm{C}-\mathrm{D})$ in soybean plants after 7 days of exposure to drought stress $(\mathrm{A}, \mathrm{C})$ and after 3 days $(\mathrm{B}, \mathrm{D})$ of recovery under well-irrigated conditions. Vertical bars represent standard deviation of the mean $(n=4)$. ns: not significant. ${ }^{* *}$ : statistical significance at $1 \%$ by $\mathrm{F}$ test.
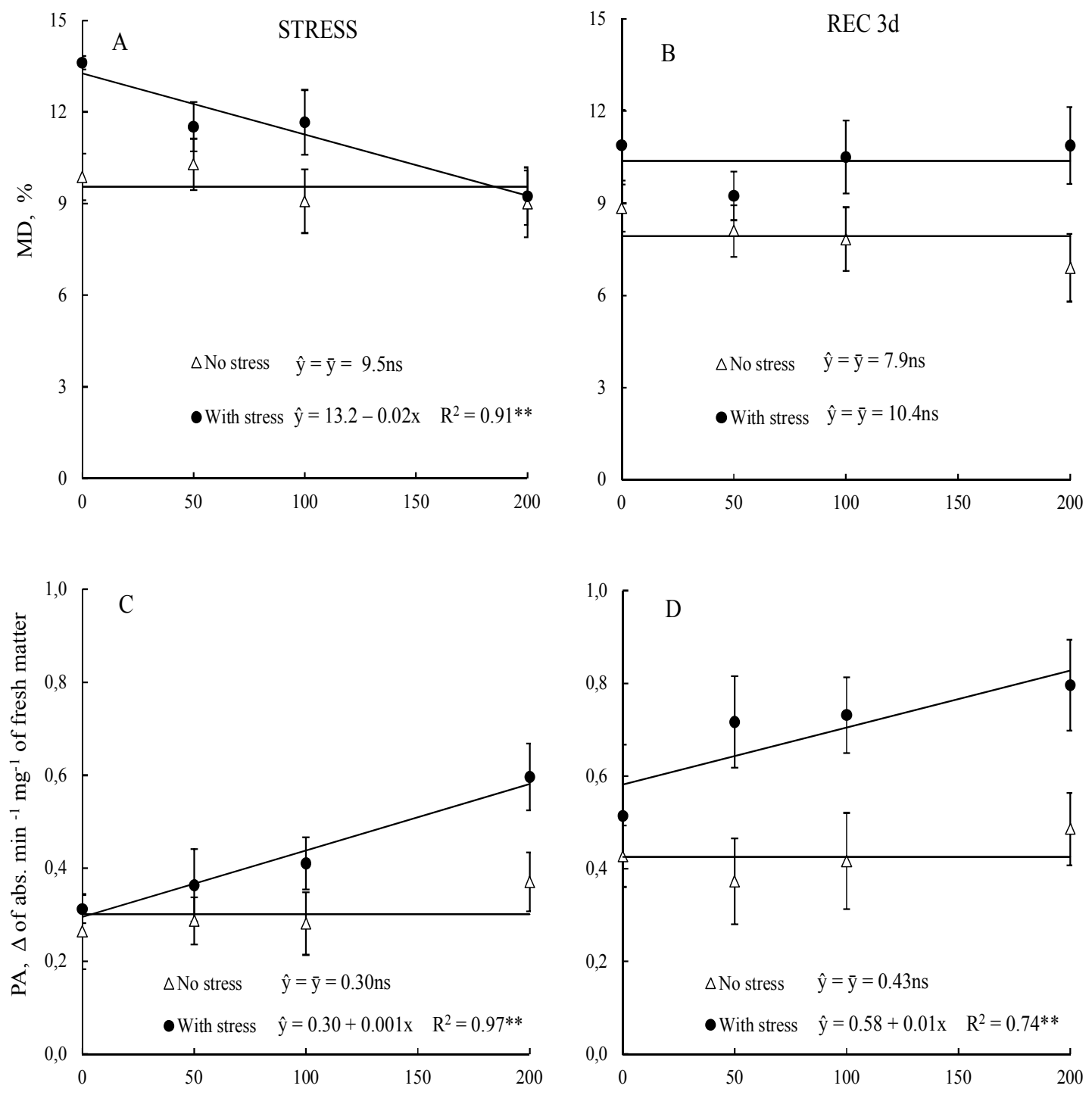

Si applied, $\mathrm{mg} \mathrm{kg}^{-1}$ 
In conditions of drought stress, electrolyte leakage from cells of soybean leaves, after seven days of exposure to stress, were affected by $\mathrm{Si}$ rates (Figure 3a). Increasing levels of Si linearly decreased the electrolyte leakage from cells of soybean leaves. With application of $200 \mathrm{mg} \mathrm{kg}$, the electrolyte leakage was equal to that under wellirrigated conditions (Figure. 3a).

This finding indicates that the supply of $\mathrm{Si}$ increased the membrane integrity and, therefore, decreased electrolyte leakage from cells. Similar results were reported by Gunes et al. (2008) in sunflower plants, who found that $\mathrm{Si}$ application minimized the membrane damage due to the drought. In rice plants, Agarie et al. (1998) found that the $\mathrm{Si}$ application reduced electrolyte leakage from cells, preventing the structural and functional impairment of the cell membrane of plants. According to Barbosa-Filho et al. (2001), the presence of Si in the cell walls of plants can increase the lignin and hemicellulose content, increasing the rigidity of the cell.

In general, the higher peroxidase enzyme activity was obtained under drought stress and can be attributed to the plant defense mechanisms against free radical formation resulting from water deficit. The increased of antioxidant enzymes activity such as peroxidase, under drought stress is usually reported in the literature for several plant species (XIONG et al., 2002; ZOZ et al., 2013), and constitutes a mechanism of plant tolerance to water deficit. Foyer et al. (1994) reported that for the organelle protections and cell membranes from the damaging effects of ROS, produced when plants are exposed some stress type, the plants develop a complex defense mechanism, including an enzyme system comprising several enzymes, among these the peroxidase. Zoz et al. (2013) concluded that the peroxidase enzyme activity may be used in the selection of soybean genotypes with greater tolerance to drought.
The peroxidase enzyme activity of soybean leaves was only affected by Si rates under drought stress conditions in the both evaluations (Figure 3c and $3 \mathrm{~d}$ ). Increasing levels of Si linearly increased the peroxidase activity. These results indicate that Si stimulated the defense mechanisms of soybean plants that were not sufficient to mitigate the negative effects on RWC (Figure 2). Gunes et al. (2008) found that $\mathrm{Si}$ application reduced the deleterious effects of drought by increase the stomatal resistance, proline and hydrogen peroxide contents and lipid peroxidation on sunflower leaves. On the other hand, the highest peroxidase activity after three days of recovery under well-irrigated conditions (Figure 3d) compared to activity after seven days of exposure to drought stress (Figure 3c) indicates that this element accelerated the response of peroxidase activity to the stress occurred. Silicon can stimulate the natural defense mechanisms of plants through of the production of phenolic compounds, chitinases, peroxidases and lignin accumulation (FAWE et al., 1998).

\section{Plant growth and nutrient accumulation}

The plant growth of soybean was negatively affected by the presence of Si (Figure 4). Increasing levels of Si linearly decreased the leaf area, shoot dry matter, root dry matter and total dry matter of soybean plants under well-irrigated conditions. The reduction in dry matter production with increasing of $\mathrm{Si}$ rates indicates possible phytotoxic effects of this element to soybean plants. In general, the beneficial effects of Si to plants are usually reported in species accumulator this element, as Gramineae and Cyperacea (BARBOSA-FILHO et al., 2001; KORNDÖRFER et al., 2004). Soybean is considered an intermediate plant in the Si accumulation and therefore, the response of this crop to the Si appears to be unlikely. 
Figure 4. Effects of silicon (Si) application rates on the leaf area (LA, in A), shoot dry matter (SDM, in B), root dry matter (RDM, in C) and total dry matter (TDM, in D) in soybean plants subjected to well-irrigated or drought stress conditions, imposed at the beginning of flowering (R1-R2). Vertical bars represent standard deviation of the mean ( $\mathrm{n}$ $=4)$. ns: not significant. ${ }^{*}$ and $* *$ : statistical significance at $5 \%$ and $1 \%$, respectively, by $\mathrm{F}$ test.
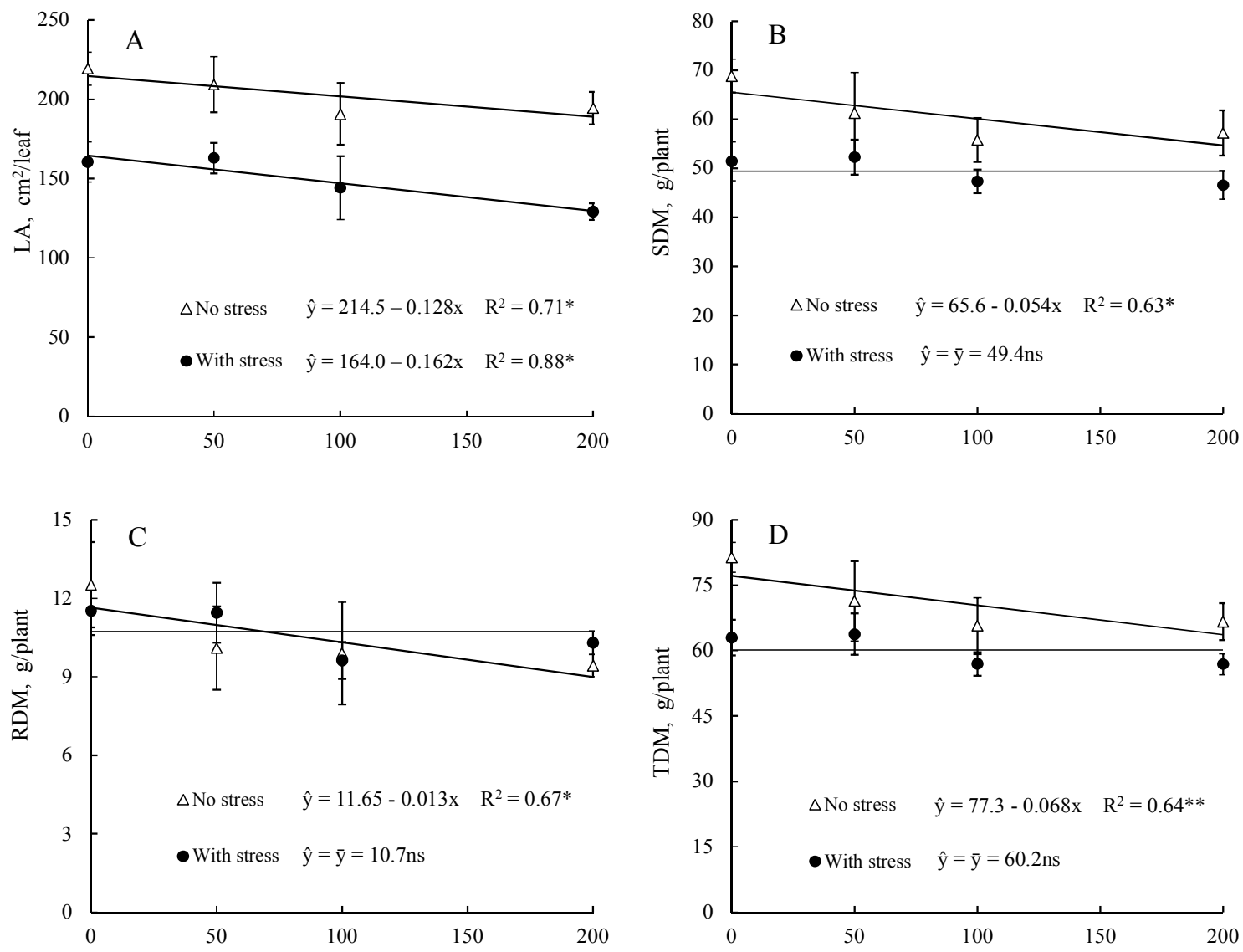

Si applied, $\mathrm{mg} \mathrm{kg}^{-1}$

In conditions of drought stress, the dry matter production of soybean plants was not affected by $\mathrm{Si}$ rates (Figure 4). These finding indicates that the apparent phytotoxic effect of $\mathrm{Si}$ on soybean plants was not evident as occurred in well-irrigated conditions. Such inference is possibly due to the decrease of membrane damage (Figure 3a) and increases of peroxidase activity (Figure $3 \mathrm{c}$ and $3 \mathrm{~d}$ ) with the increase of Si rates under drought stress.

The lowest dry matter production of soybean was obtained when plants were subjected to drought stress, regardless of silicon rates (Figure 4). These data report the typical response of plants to water stress usually reported in the literature (HATTORI et al., 2005; FLEXAS et al., 2006; ZOZ et al., 2013). One of the first processes affected in response to decreased soil water availability is cell expansion, highly dependent process turgidity of the plants. However, with the advancement of drought, other physiological processes are affected, with direct effects on the photoassimilates accumulation by the plant, reduction in the carbon assimilation rate and relative growth rate (SANTOS; CARLESSO, 1998, CHAVES et al., 2002; SILVA et al., 2007). As a result of these effects, there is a reduction in dry matter production. The reduced of leaf productions occurs as a defense reaction of plants to drought, reducing transpiration rate and therefore, the water loss to the atmosphere. 
Silicon supply did not affect the $\mathrm{N}$ concentration of soybean leaves under well-irrigated conditions (Figure 5a). Mauad et al. (2003) also found no effect of $\mathrm{Si}$ rates in the $\mathrm{N}$ concentration in rice plants. However, Souza et al. (2005) found that the application of calcium silicate reduced the $\mathrm{N}$ concentration in the brachiaria plants. Thus, it is found that the effect of $\mathrm{Si}$ on $\mathrm{N}$ uptake is even inconclusive. When soybean was subjected to drought stress the $\mathrm{N}$ concentration was reduced with the increase of Si (Figure 5a). Under conditions of water stress, soybean plants may show changes in the enzyme activity of carbon and nitrogen metabolism (SANTOS; CARLESSO, 1998; FLEXAS et al., 2006).

Figure 5. Effects of silicon ( $\mathrm{Si}$ ) application rates on the content of nitrogen (A), phosphorus (B), potassium (C) and silicon (D) in the leaves of soybean subjected to well-irrigated or drought stress conditions, imposed at the beginning of flowering $(\mathrm{R} 1-\mathrm{R} 2)$. Vertical bars represent standard deviation of the mean $(\mathrm{n}=4)$. ns: not significant. *: statistical significance at $5 \%$ by $\mathrm{F}$ test.
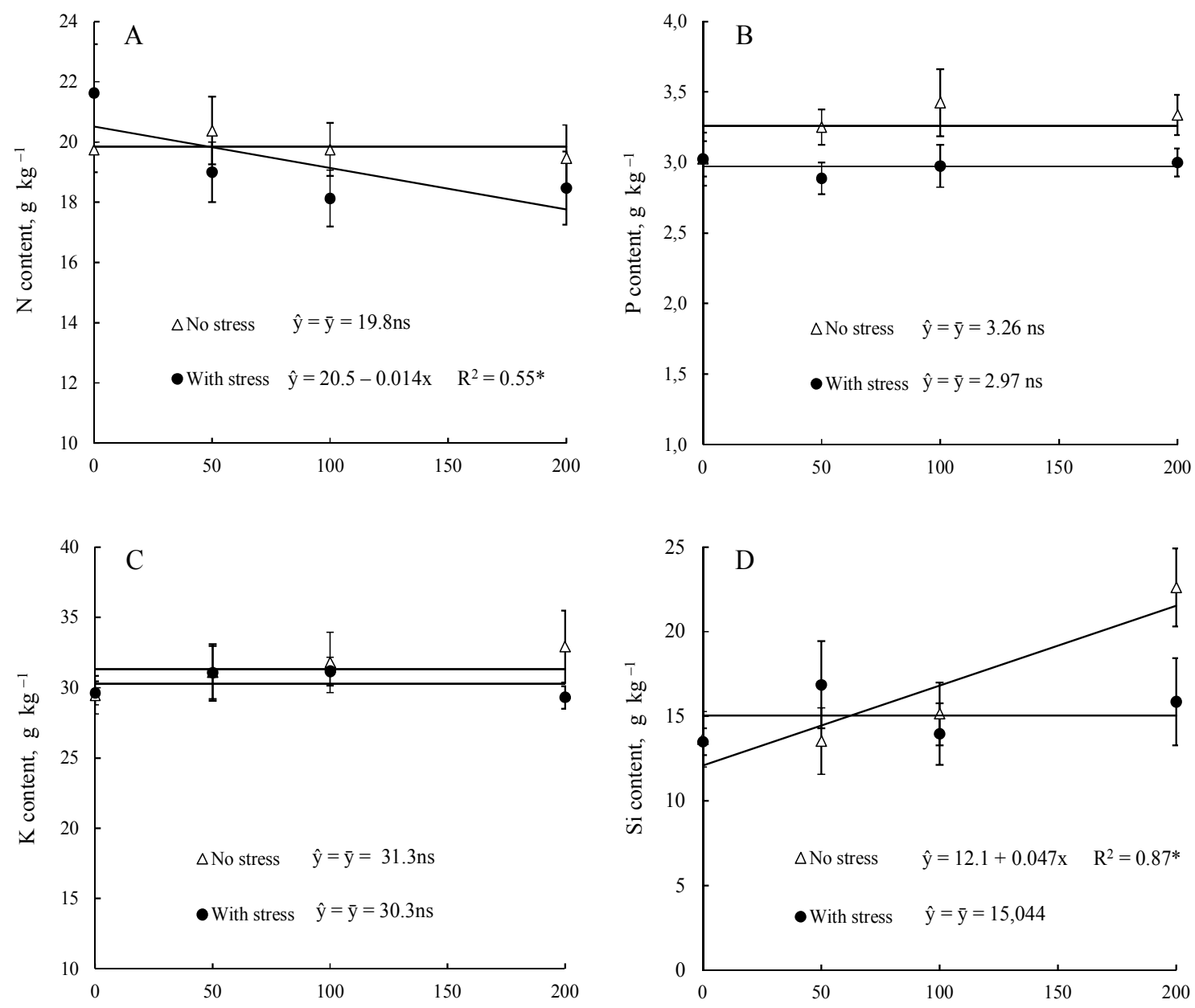

Si applied, $\mathrm{mg} \mathrm{kg}^{-1}$ 
The $\mathrm{P}$ and $\mathrm{K}$ concentration in the soybean leaves was not affected by $\mathrm{Si}$ application in both water regimes (Figure $5 \mathrm{~b}$ and $5 \mathrm{c}$, respectively), confirming the results obtained by Souza et al. (2005). The lowest $\mathrm{P}$ and $\mathrm{K}$ concentration in plants under water deficit can be attributed to reduce in the uptake of these nutrients, due to the reduction of soil water availability. According to Marschner (1995), the transport mechanism of $\mathrm{P}$ and $\mathrm{K}$ to plant roots is diffusion, a process highly dependent of soil moisture.

The application of $\mathrm{Si}$ rates linearly increased the concentration of this element in soybean leaves under well-irrigated conditions (Figure 5d). In part, these results may be attributed to reduction of leaf area and dry matter production (Figure 4), resulting in higher concentration of Si on soybean leaves. In conditions of drought stress, the Si did not affect the concentration of the element in soybean leaves (Figure 5d). These results can be explained due to the reduction in water availability in the soil and the stable absorption of $\mathrm{Si}$ in drought stress conditions.

\section{Conclusions}

The relative water content in soybean leaves decreased progressively with increasing Si rates in the soil.

Silicon supply in soil with average content of this element reduced dry matter production of soybean plants under well-irrigated conditions and caused no effect on dry matter under drought stress.

The nitrogen uptake by soybean plants is reduced with the Si application under drought stress conditions.

Silicon stimulated the defense mechanisms of soybean plants, which were not sufficient to mitigate the negative effects of drought stress on the relative water content and dry matter production.

\section{Acknowledgements}

To CAPES (Coordination for the Improvement of Higher Education Personnel), ARAUCARIA FOUNDATION (Araucaria Foundation for the Support Scientific and Technological Development of the State of Paraná) and CNPq (National Council for Scientific and Technological Development) for financial support.

\section{References}

AGARIE, S.; HANAOKA, N.; UENO, O.; MIYAZAKI, A.; KUBOTA, F.; AGTA, W.; KAUFMAN, P. B. Effects of silicon on tolerance to water deficit and heat stress in rice plants (Oryza sativa L.), monitored by electrolyte leakage. Plant Production Science, Tóquio, v. 1, n. 2, p. 96-103, 1998.

BARBOSA-FILHO, M. P.; SNYDER, G. H.; FAGERIA, N. K.; DATNOFF, L. E.; SILVA, O. F. Silicato de cálcio como fonte de silício para o arroz de sequeiro. Revista Brasileira de Ciência do Solo, Viçosa, MG, v. 25, n. 2, p. 325-330, 2001.

BARRS, H. D. Effect of cycle variations in gas exchange under constant environmental conditions on the ratio of transpiration to net photosynthesis. Physiologia Plantarum, Malden, v. 21, n. 5, p. 918-929, 1968.

BELTRANO, J.; RONCO, M. G. Improved tolerance of wheat plants (Triticum aestivum L.) to drought stress and rewatering by the arbuscular mycorrhizal fungus Glomus claroideum: effect on growth and cell membrane stability. Brazilian Journal of Plant Physiology, Londrina, v. 20, n. 1, p. 29-37, 2008.

BENINCASA, M. M. P. Análise de crescimento de plantas: noções básicas. Jaboticabal: FUNEP, 2003. 41 p.

CHAVES, M. M.; PEREIRA, J. S.; MAROCO, J.; RODRIGUES, M. L.; RICARDO, C. P. P.; OSÓRIO, M. L.; CARVALHO, I.; FARIA, T.; PINHEIRO, C. How plants cope with stress in the field:photosynthesis and growth. Annals of Botany, Oxford, v. 89, n. 7, p. 907916, 2002.

CRUSCIOL, C. A. C.; PULZ, A. L.; LEMOS, L. B.; SORATTO, R. P.; LIMA, G. P. P. Effects of silicon and drought stress on tuber yield and leaf biochemical characteristics in potato. Crop Science, Madison, v. 49, n. 3, p. 949-954, 2009. 
DESHMUKH, R.; VIVANCOS, J.; GUÉRIN, V.; SONAH, H.; LABBÉ, C.; BELZILE, F.; BELANGER, $R$. Identification and functional characterization of silicon transporters in soybean using comparative genomics of major intrinsic proteins in Arabidopsis and rice. Plant Molecular Biology, Bethesda, v. 83, n. 4-5, p. 303-315, 2013.

EMPRESA BRASILEIRA DE PESQUISA AGROPECUÁRIA - EMBRAPA. Manual de análises químicas de solos, plantas e fertilizantes. 2. ed. Brasília: Informação Tecnológica, 2009. 628 p.

Manual de métodos de análise de solo. Rio de Janeiro: Embrapa Solos, 1997. 212 p.

FAWE, A.; ABOW-ZAID, M.; MENZEIS, J. G.; BELANGER, R. R. Silicon-mediated accumulation of flavonoid phytoalexins in cucumber. Phytopathology, Saint Paul, v. 88, n. 5, p. 396-401, 1998.

FERRAZ, R. L. S.; BELTRÃO, N. E. M.; MELO, A. S.; MAGALHÃES, I. D.; FERNANDES, P. D.; ROCHA, M. $\mathrm{S}$. Trocas gasosas e eficiência fotoquímica de cultivares de algodoeiro herbáceo sob aplicação de silício foliar. Semina: Ciências Agrárias, Londrina, v. 35, n. 2, p. 735748, 2014.

FLEXAS, J.; RIBAS-CARBO, M.; BOTA, J.; GALMES, J.; HENKLE, M.; MARTINEZ-CANELLAS, S.; MEDRANO, H. Decreased rubisco activity during water stress is not induced by decreased relative water content but related to conditions of low stomatal conductance and chloroplast $\mathrm{CO}_{2}$ concentration. New Phytologist, Bethesda, v. 172, n. 1, p. 73-82, 2006.

FOYER, C. H.; LELANDAIS. M.; KUNERT, K. J. Photooxidative stress in plants. Physiologia Plantarum, Malden, v. 92, n. 4, p. 696-717, 1994.

GAO, X.; ZOU, C.; WANG, L.; ZHANG, F. Silicon decreases transpiration rate and conductance from stomata of maize plants. Journal of Plant Nutrition, New York, v. 29, n. 9, p. 1637-1647, 2006.

GONG, H.; ZHU, X.; CHEN, K.; WANG, S.; ZHANG, C. Silicon alleviates oxidative damage of wheat plants in pots under drought. Plant Science, Bibao, v. 169, n. 2, p. 313-321, 2005.

GUNES, A.; PILBEAM, D. J.; INAL, A.; COBAN, $S$. Influence of silicon on sunflower cultivars under drought stress. I: Growth, antioxidant mechanisms, and peroxidation and lipid peroxidation. Communications in Soil Science and Plant Analysis, Madison, v. 39, n. 13-14, p. 1885-1903, 2008.
HAMMERSCHMIDT, R.; NUCKLES, E. M.; KUC, J. Association of enhanced peroxidase activity with induced systemic resistance of cucumber to Colletotrichum lagenarium. Physiological Plant Pathology, New York, v. 20, n. 1, p. 73-82, 1982.

HATTORI, T.; INANAGA, S.; ARAKI, H.; PING, A.; MORITA, S.; LUXOVÁ, M.; LUX, A. Application of silicon enhanced drought tolerance in Sorghum bicolor. Plant Physiology, Madison, v. 123, n. 4, p. 459-466, 2005.

KORNDÖRFER, G. H.; PEREIRA, H. S.; NOLLA, A. Análise de silício: solo, planta e fertilizante. Uberlândia: UFU, 2004. 34 p. (Boletim técnico, 2).

KRON, A. P.; SOUZA, G. M.; RIBEIRO, R. V. Water deficiency at different developmental stages of Glycine max can improve drought tolerance. Bragantia, Campinas, v. 67, n. 1, p. 43-49, 2008.

LUTTS, S.; KINET, J. M.; BOUHARMONT, J. Effects of salt stress on growth, mineral nutrition and proline accumulation in relation to osmotic adjustment in rice (Oryza sativa L.) cultivars differing in salinity resistance. Journal of Plant Growth Regulation, New York, v. 19, n. 2, p. 207-218, 1996.

MA, J. F. Role of silicon in enhancing the resistance of plants to biotic and abiotic stresses. Soil Science and Plant Nutrition, Tokyo, v. 50, n. 1, p. 11-18, 2004.

MA, J. F.; YAMAJI, N. Silicon uptake and accumulation in higher plants. Trends Plant Science, Cambridge, v. 11, n. 8, p. 342-397, 2006.

MARSCHNER, H. Mineral nutrition of higher plant. $2^{\text {th }}$ ed. New York: Academic Press, 1995. 624 p.

MAUAD, M.; CRUSCIOL, C. A. C.; GRASSI-FILHO, H. Produção de massa seca e nutrição de cultivares de arroz de terras altas sob condição de déficit hídrico e adubação silicatada. Semina: Ciências Agrárias, Londrina, v. 32, n. 3, p. 939-948, 2011.

MAUAD, M.; GRASSI-FILHO, H.; CRUSCIOL, C. A. C.; CORRÊA, J. C. Teores de silício no solo e na planta de arroz de terras altas com diferentes doses de adubação silicatada e nitrogenada. Revista Brasileira de Ciência do Solo, Viçosa, MG, v. 27, n. 5, p. 867-873, 2003.

MIAO, B. H.; HAN, X. G.; ZHANG, W. H. The ameliorative effect of silicon on soybean seedlings grown in potassium-deficient medium. Annals of Botany, Oxford, v. 105, n. 6, p. 967-973, 2010.

MITANI, N.; MA, J. F. Uptake system of silicon in different plant species. Journal of Experimental Botany, Oxford, v. 56, n. 414, p. 1255-1261, 2005. 
PULZ, A. L.; CRUSCIOL, C. A. C.; LEMOS, L. B.; SORATTO, R. P. Influência de silicato e calcário na nutrição, produtividade e qualidade da batata sob deficiência hídrica. Revista Brasileira de Ciência do Solo, Viçosa, MG, v. 32, n. 4, p. 1651-1659, 2008.

SANTOS, R. F.; CARLESSO, R. Déficit hídrico e os processos morfológicos e fisiológicos das plantas. Revista Brasileira de Engenharia Agrícola e Ambiental, Campina Grande, v. 2, n. 3, p. 287-294, 1998.

SARTO, M. V. M.; LANA, M. C.; RAMPIM, L.; ROSSET, $J$. S.; WOBETO, J. R. Effects of silicate application on soil fertility and wheat yield. Semina: Ciências Agrárias, Londrina, v. 36, n. 6, p. 4071-4082, 2015.

SILVA, M. A.; JIFON, J. L.; SILVA, J. A. G.; SHARMA, V. Use of physiological parameters as fast tools to screen for drought tolerance in sugarcane. Brazilian Journal of Plant Physiology, Londrina, v. 19, n. 3, p. 193-201, 2007.
SOUZA, G. M.; CARDOSO, V. J. M. Toward a hierarchical concept of plant stress. Israel Journal of Plant Sciences, Jerusalém, v. 51, n. 1, p. 29-37, 2003.

SOUZA, G. M.; VIANA, J. O. F.; OLIVEIRA, R. F. Asymmetrical leaves induced by water deficit show asymmetric photosynthesis in common bean. Brazilian Journal of Plant Physiology, Londrina, v. 17, n. 2, p. 223-227, 2005.

XIONG, L.; SCHUMAKER, K. S.; ZHU, J. K. Cell signaling during cold, drought and salt stress. The Plant Cell, Waterbury, v. 14, n. 2, p. 165-183, 2002.

ZOZ, T.; STEINER, F.; GUIMARÃES, V. F.; CASTAGnARA, D. D.; MEINERZ, C. C.; FEY, R. Peroxidase activity as an indicator of water deficit tolerance in soybean cultivars. Bioscience Journal, Uberlandia, v. 29, n. 5, p. 1664-1671, 2013. 
